
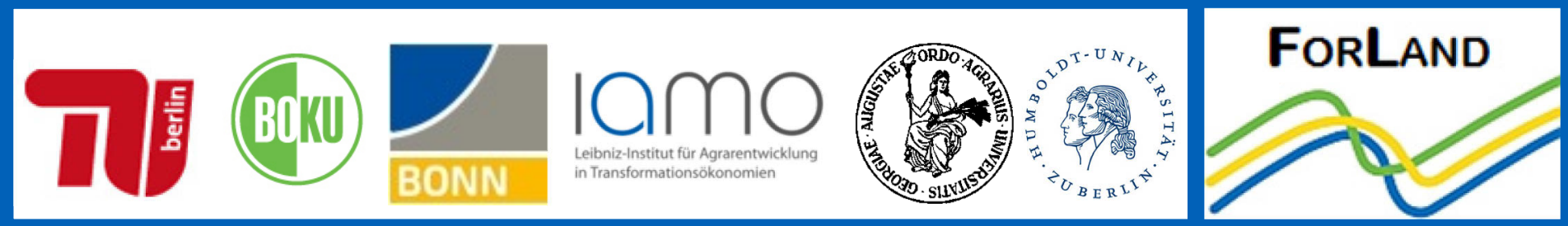

\title{
What Moves the German Land Market? A Decomposition of the Land Rent-Price Ratio
}

Jana Plogmann, Oliver Mußhoff, Martin Odening, Matthias Ritter

\section{FORLand-Working Paper 05 (2018)}

\author{
Published by
}

DFG Research Unit 2569 FORLand, Humboldt-Universität zu Berlin Unter den Linden 6, D-10099 Berlin

https://www.forland.hu-berlin.de (C) $\mathbb{Q} \Theta \Theta$

Tel +49 (30) 2093 46845, Email gabriele.wuerth@agrar.hu-berlin.de

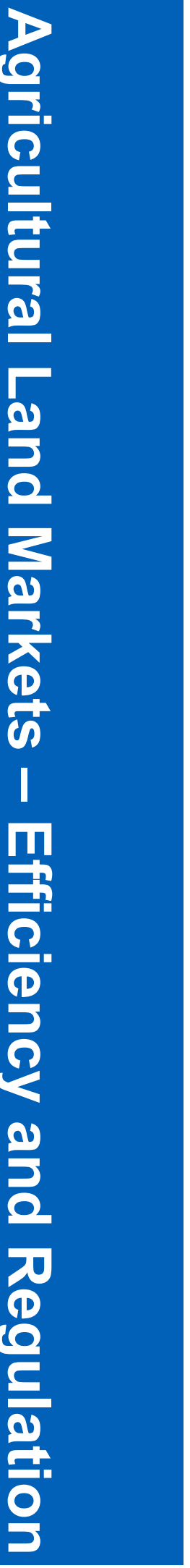




\title{
What Moves the German Land Market? A Decomposition of the Land Rent-Price Ratio
}

\author{
Jana Plogmann*, Oliver Mußhoff ${ }^{* *}$, Martin Odening ${ }^{* *}$, Matthias Ritter ${ }^{* \star *}$
}

\author{
October 2018
}

\begin{abstract}
The price increases on agricultural land markets in the last decade have triggered a debate about land as an attractive investment opportunity for agricultural and non-agricultural investors. In a static environment, the rent-price ratio provides a first indicator of the profitability of an investment in land. In this paper, we apply the dynamic Gordon growth model to Western Germany and decompose the rent-price ratio into the expected present values of rental growth rates, real interest rates, and a land premium, i.e., the excess return on investment. This analysis reveals that the recent price surge on agricultural land markets was not unprecedented; that the land market rent-price ratio is rather low compared to other markets and varies considerably among federal states; and that (expected) premia for land are mostly negative, rendering investments in farmland unprofitable for financial investors. Finally, we find that changing expected present values of returns on land investments are the major driver for land price volatility.
\end{abstract}

Keywords: Agricultural land market; rent-price ratio; Campbell-Shiller decomposition; dynamic Gordon growth model

JEL codes: $\quad$ C32, G12, Q15

\section{Acknowledgements}

Financial support from the German Research Foundation (DFG) through Research Unit 2569 "Agricultural Land Markets - Efficiency and Regulation" is gratefully acknowledged.

* Jana Plogmann (contact author), jana.maria.plogmann@agrar.hu-berlin.de, Georg-August-Universität Göttingen, Department of Agricultural Economics and Rural Development and Humboldt-Universität zu Berlin, Department of Agricultural Economics, Unter den Linden 6, D-10099 Berlin

* Prof. Dr. Oliver Mußhoff, oliver.musshoff@agr.uni-goettingen.de, Georg-August-Universität Göttingen, Department of Agricultural Economics and Rural Development, Platz der Göttinger Sieben 5, D-37073 Göttingen

*** Prof. Dr. Martin Odening, m.odening@agrar.hu-berlin.de, Humboldt-Universität zu Berlin, Department of Agricultural Economics, Unter den Linden 6, D-10099 Berlin

**** Prof. Dr. Matthias Ritter, matthias.ritter@agrar.hu-berlin.de, Humboldt-Universität zu Berlin, Department of Agricultural Economics, Unter den Linden 6, D-10099 Berlin 


\section{Introduction}

The German agricultural land market has witnessed a sharp price surge in the last decade. Indeed, the average price for arable land increased from 9,205 euros per hectare in 2007 to 24,064 euros per hectare in 2017 (STATISTISCHES BUNDESAMT 2018). A similar development can be observed in other European countries as well, e.g. in Great Britain (EUROPEAN COMMISSION 2018). In light of the importance of land as a production factor in agriculture, it is not surprising that the booming land market has become the subject of extensive empirical research. These research activities address different research questions. A first strand of literature focuses on understanding the specific role of economic determinants of land prices. This kind of analysis is usually conducted in a hedonic pricing framework. LATRUFFE and LE MOUËL (2009) assert that agricultural support policy instruments contribute to increased land prices in general. Likewise, HENNIG et al. (2014) report a significant positive effect of payment entitlements on land rental prices. Focusing on biogas subsidies, HABERMANN and BREUSTEDT (2011) and HENNIG and LATACZ-LOHMANN (2017) investigate how and where rental land prices in Northern Germany are inflated by bioenergy feed-in tariffs. In the same vein, RITTER et al. (2015) document a positive relationship between arable land prices and the density of wind turbines in the state of Brandenburg, Germany. A meta-analysis on the impact of subsidies on agricultural land prices is provided by FEICHTINGER and SALHOFER (2013). A further potential cause for increasing land prices that has been studied is the heightened interest of nonagricultural investors in the aftermath of the financial crisis. It has been conjectured that the lack of profitable investment alternatives in the traditional financial markets has redirected a flow of external capital into the agricultural sector (DEININGER and BYERLEE 2011). This additional demand from outside the sector has aggravated the price pressure on land markets. There are, however, only a few empirical studies that try to provide evidence for this "investor hypothesis", such as FORSTNER et al. (2011) and HÜTTEL et al. (2016) for the case of Eastern Germany. Finally, urban sprawl is often claimed to be a major price driver on agricultural land markets, particularly in densely populated, industrialized countries (KUETHE et al. 2011, ZHANG and NICKERSON 2015, LEHN and BAHRS 2018). According to this view, high real estate prices on the fringe of metropolitan areas spill over to rural land markets.

A different strand of literature scrutinizes from a more general perspective whether soaring land prices can be traced back to economic fundamentals or whether speculative bubbles exist. The distinction between price changes due to fundamental factors and "excessive" speculation is crucial for the current policy debate on the regulation of agricultural land markets. The presence of speculative bubbles can be considered as market failure and such an incidence may warrant market interventions, such as direct capping of prices or refusal of "abnormally high" bids in land tenures. For the U.S. land market, FALK (1991) and FALK and LEE (1998) found that land price changes cannot be fully explained by changes in cash rents, at least in the short run. Also POWER and TURVEY (2010) found evidence for short run price bubbles. In contrast, GLOY et al. (2011) conclude from their study that recent U.S. farmland values are in line with economic fundamentals. This view is also supported by OLSEN and STOKES (2015), who fail to reject the no-bubbles hypothesis. TIETZ and FORSTNER (2014) arrive at a similar conclusion for the agricultural land market in Germany. 
The aforementioned work on speculative bubbles in land markets rests on the present value model of asset prices, according to which land prices can be derived from appropriately discounted future returns (cash rents and price changes) of owning this asset. In this view, the relationship between land rental prices and sales prices should be stationary unless a bubble drives a wedge between them. The present value model of land prices also constitutes the theoretical underpinning of this article. However, instead of focusing on the presence of bubbles, we aim at decomposing the rent-price ratio into various fundamental components.

The idea of decomposing the rent-price ratio into the aforementioned components has been proposed by CAMPBELL and SHILLER (1988) in the context of stock markets and has been used for numerous empirical applications in financial markets since then. For example, SHILLER and BELTRATTI (1992) analyzed the U.S. and the British stock market to explain co-movements between stock prices and bond yields. VUOLTEENAHO (2002) applied the method to firm-level stock returns and PLAZZl et al. (2006) to the commercial real estate market in the U.S. CAMPBELL et al. (2009) were the first in adapting this concept to real estate markets. They find that housing premia account for a considerable part of fluctuations in the rent-price ratio in the U.S. housing market, while the covariances of interest rate, rental growth rate and housing premia dampen the variance of the rent-price ratio. Similar findings are reported by KIM and LIM (2014) for the Irish housing market. KISHOR and MORLEY (2015) modify the CampbellShiller decomposition and allow for a nonstationary residual that captures deviations of the rent-price ratio value from its long-run stationary value. Their analysis shows that much of the variance in the rent-price ratio can be explained by the variation in expected housing returns.

Given the theoretical and empirical relevance of the present value model for financial assets, it is somewhat surprising that the variance decomposition of the rent-price ratio has not been applied to agricultural land markets so far. The objective of the paper is to address this research gap. The economic factors that are considered in the decomposition include inflation, real interest rates, the growth rate of rental prices, and a risk premium. Disentangling these factors can help to answer a couple of relevant research questions: Are land prices driven by inflation? Do market participants expect growing cash rents? Can land market investors expect returns that exceed real interest rates? What factors contribute to the variability of the rent-price ratio in land markets? In our empirical application we analyze the relationship of rental prices and sales prices of agricultural land for Western Germany as a whole as well as for single states. We find that the rent-price ratio exhibits considerable variation over time and among states.

The remainder of this article is structured as follows: In the next section, we briefly review the Campbell-Shiller variance decomposition of the rent-price ratio and explain how we implement this approach empirically. Section 3 presents the study region and details the derivation of the model variables from the available data set. The empirical results are reported in Section 4 and the concluding remarks in Section 5 relate our findings to the current discussion about the efficiency of agricultural land markets. 


\section{Model and empirical approach}

\subsection{The Campbell-Shiller decomposition}

The starting point of the model derivation is the definition of the return of investing into one hectare of agricultural land:

$$
\varphi_{t}=\frac{R_{t}+P_{t}-P_{t-1}}{P_{t-1}}
$$

where $R_{t}$ denotes the real rental price per hectare at time $t$ and $P_{t}$ is the real sales price of one hectare of agricultural land at time $t$. The log rent-price ratio is then defined as

$$
r_{t}-p_{t}=\log \left(\frac{R_{t}}{P_{t}}\right)
$$

Using these definitions and applying a first order Taylor approximation, CAMPBELL and SHILLER (1988) show that the log rent-price ratio $r_{t}-p_{t}$ equals the expected net present value of the future return minus the future real rental growth:

$$
r_{t}-p_{t}=k+E_{t} \sum_{j=0}^{\infty} \rho^{j} \varphi_{t+1+j}-E_{t} \sum_{j=0}^{\infty} \rho^{j} \Delta r_{t+1+j}
$$

with

$$
\begin{aligned}
\rho & =\left(1+e^{\overline{r-p}}\right)^{-1}, \\
k & =(1-\rho)^{-1}\left[\ln (\rho)+(1-\rho) \ln \left(\frac{1}{\rho}-1\right)\right],
\end{aligned}
$$

where $\varphi$ is the gross real return, $\Delta r$ is the growth rate of real rents, $\rho$ is a discount factor to calculate the present value of future returns and rents, and $k$ is a constant of linearization holding the level of the rent-price ratio. The discount factor $\rho$ is linked to the average of the rent-price ratio and results from the first-order Taylor approximation. Eq. (3) is known as the dividend ratio-model or the dynamic version of the Gordon growth model. It asserts that the rent-price ratio is high when returns are expected to be high or when rents are expected to grow slowly. Note that the classic version of the Gordon growth model, $P_{t}=\frac{(1+\Delta r) R_{t}}{\varphi-\Delta r}$, is a special case of Eq. (3) if the future return and the future rental growth are assumed to be constant over time, i.e., if $E\left[\varphi_{t+1}\right]=\varphi$ and $E\left[R_{t+1}\right]=(1+\Delta r) R_{t}$. The simple present value for land prices, $P=\frac{R}{\varphi}$, is obtained in case the growth rate of land rents $\Delta r$ is zero. By relaxing the assumptions of a constant growth rate, the dynamic version of the Gordon growth model can address many of the inconsistencies of the simple present value model that have been criticized, for example by CLARK et al. (1993).

Following CAMPBELL et al. (2009) and KIM and LIM (2014), the model can be modified by decomposing the return to agricultural land $\varphi$ into the real risk-free interest rate $i$ and the excess return over the real risk-free interest rate, $\pi$, called 'land premium' hereafter with $\pi_{t}=\varphi_{t}-i_{t}$. Then, the log rent-price ratio from Eq. (3) can be expressed as 


$$
r_{t}-p_{t}=k+E_{t} \sum_{j=0}^{\infty} \rho^{j} i_{t+1+j}+E_{t} \sum_{j=0}^{\infty} \rho^{j} \pi_{t+1+j}-E_{t} \sum_{j=0}^{\infty} \rho^{j} \Delta r_{t+1+j} .
$$

Finally, introducing the following definitions for the expected present values of $\varphi_{t}, i_{t}, \pi_{t}$ and $\Delta r_{t}$

$$
\begin{array}{ll}
\Phi_{t}=E_{t} \sum_{j=0}^{\infty} \rho^{j} \varphi_{t+1+j}, & I_{t}=E_{t} \sum_{j=0}^{\infty} \rho^{j} i_{t+1+j}, \\
\Pi_{t}=E_{t} \sum_{j=0}^{\infty} \rho^{j} \pi_{t+1+j}, & G_{t}=E_{t} \sum_{j=0}^{\infty} \rho^{j} \Delta r_{t+1+j},
\end{array}
$$

the rent-price ratio model can be stated as:

or

$$
\begin{gathered}
r_{t}-p_{t}=k+\Phi_{t}-G_{t} \\
r_{t}-p_{t}=k+\Pi_{t}+I_{t}-G_{t} .
\end{gathered}
$$

\subsection{Implementing the dynamic Gordon growth model}

To implement the dynamic version of the Gordon growth model, the unobserved expectations of the present values of future returns, premia, interest rates and rental growth rates (Eq. (5)) have to be estimated. Two different options to estimate these expectations are proposed in the literature. Among these is the vector autoregressive (VAR) approach as introduced by CAMPBELL and SHILLER (1988) and later applied by CAMPBELL and AMMER (1993), CAMPBELL et al. (2009), and AMBROSE et al. (2013). Alternatively, KISHOR and MORLEY (2014) and KIM and LIM (2014) suggest a state space model that can be estimated by a Kalman Filter. In this paper, we opt for the VAR approach as it is most appropriate to consider the interdependencies between the components (CAMPBELL 1991).

A standard first order VAR is defined as

$$
Z_{t}=A Z_{t-1}+\varepsilon_{t}
$$

where $A$ is the coefficient matrix, $Z_{t}$ is the vector of variables, and $\varepsilon_{t}$ is an error term. In our case, $Z_{t}$ is given by $Z_{t}=\left(\pi_{t}, i_{t}, \Delta \mathrm{r}_{t}\right)$, and the estimated expected present values are computable by

$$
\hat{A}(I-\rho \hat{A})^{-1} Z_{t},
$$

where $\hat{A}$ denotes the estimate of the coefficient matrix $A, I$ is the identity matrix, and $\rho$ the discount factor given by Eq. (3). The first three elements of the resulting vector are the estimated expected present values. Given these estimates, the rent-price ratio for each point in time is given by

$$
r_{t}-p_{t}=k+\widehat{\Pi}_{t}+\hat{I}_{t}-\widehat{G}_{t}+e_{t}
$$


with forecast discrepancy $e_{t}$. By definition, the variance of $r_{t}-p_{t}$ can be decomposed as follows

$$
\begin{aligned}
\operatorname{var}\left(r_{t}-p_{t}\right)= & \operatorname{var}\left(\hat{I}_{t}\right)+\operatorname{var}\left(\widehat{\Pi}_{t}\right)+\operatorname{var}\left(\widehat{G}_{t}\right)+\operatorname{var}\left(e_{t}\right) \\
& +2 \operatorname{cov}\left(\hat{I}_{t}, \widehat{\Pi}_{t}\right)-2 \operatorname{cov}\left(\hat{I}_{t}, \widehat{G}_{t}\right)+2 \operatorname{cov}\left(\hat{I}_{t}, e_{t}\right) \\
& -2 \operatorname{cov}\left(\widehat{\Pi}_{t}, \widehat{G}_{t}\right)+2 \operatorname{cov}\left(\widehat{\Pi}_{t}, e_{t}\right)-2 \operatorname{cov}\left(\widehat{G}_{t}, e_{t}\right)
\end{aligned}
$$

where $\operatorname{var}(\cdot)$ and $\operatorname{cov}(\cdot)$ denote variances and covariances, respectively. Equations (10) and (11) form the basis for the empirical analysis in Section 4.

\section{Study region and data}

In our empirical analysis, we study the rent-price ratio in Western Germany. We will perform the analysis for all of Western Germany and for each of the eight federal states in Western Germany (excluding the two city-states) individually. Western Germany is considered an interesting study region because sales and rental prices of agricultural land as well as production and farming structures differ among federal states ${ }^{1}$. The question arises if this heterogeneity translates into differences in the level and the structure of the rent-price ratio.

Land price data from 1975-2016 are extracted from the Statistisches Jahrbuch 1976-2017 published by the Statistisches Bundesamt. ${ }^{2}$ Prices refer to agricultural land including arable land and grassland. Nominal agricultural land sales prices are available on country and federal state level on an annual basis. Land rental prices are also available at country and federal state level, but only for every second (1975-2007) or third year (after 2007) due to the frequency of the underlying Agricultural census. To conduct an analysis on a yearly basis, we linearly interpolate the rental prices. It is important to note that the rental price data reflect prices of running contracts, i.e., they reflect the average of the rent paid for agricultural land during a contract period of several years. Rental price data for newly concluded contracts would have been more suitable for our analysis since they reflect the most recent information about expected productivity of land, but unfortunately these data are not available for the desired time period. This implies that rental prices in our analysis appear more sluggish than they actually are. To conduct the analysis for Western Germany as a whole, we use federal state data on land sales and rental prices and average them using the agricultural area of every federal state as weights. Nominal prices are converted into real prices by measuring inflation with the Consumer Price Index (CPI) for Germany published by Statistisches Bundesamt. $^{3}$

In addition, the real interest rate is required for the analysis. We use the yield of government bonds with a maturity of 9 to 10 years as proxy for the nominal risk-free interest rate. This maturity is chosen since the agricultural land market is characterized by long lasting

1 We focus on Western Germany since land price data for Eastern Germany are available only since 1991.

2 All volumes of Statistisches Jahrbuch are accessible at https://www.destatis.de/DE/Publikationen/StatistischesJahrbuch/StatistischesJahrbuch.html

3 The Consumer Price Index can be found at https://www.destatis.de/DE/ZahlenFakten/GesamtwirtschaftUmwelt/Preise/Verbraucherpreisindize s/Verbraucherpreisindizes.html. 
ownerships and this is the longest maturity available over the study period. Real risk-free interest rates are computed using the Fisher equation and are the same for all states. Again, deflation is conducted via the $\mathrm{CPI}$. Since the $\mathrm{CPI}$ is subject to macroeconomic changes, its variability may be transmitted to the deflated variables in our analysis. The return to agricultural land, $\varphi_{t}$, is calculated according to Eq. (1), which implies a truncation of the study period to 1976-2016. Finally, the land premium, $\pi_{t}$, is derived as the difference between the real return and the real interest rate.

Figure 1 depicts sales and rental prices in Western Germany in nominal and real terms and reveals some noteworthy facts. In nominal terms, land prices reach a peak in 2016 after a decade of steady increase. This development is well documented and has led to concerns about the effectiveness of existing land market regulations in Germany (e.g., BUND-LÄNDERARBEITSGRUPPE "BODENMARKTPOLITIK" 2015). In real terms, however, this price boom is not unprecedented: At the beginning of the 1980s, real land prices were even higher than today, before they began to descend for more than two decades. Also, real rental prices declined between 1988 and 2006 and their current value does not exceed the peak value in 1988. In both boom periods, sales prices increased faster than rental prices. This finding may be in part explained by the aforementioned smoothing effect of persisting rental contracts. On the other hand, it could point to a price bubble, which has been found for the farmland market in the eighties in the U.S. (e.g., FALK 1991). For Germany, however, no such evidence has been reported so far (e.g., TIETZ and FORSTNER 2014).

\section{Figure 1. Sales and rental prices for Western Germany}

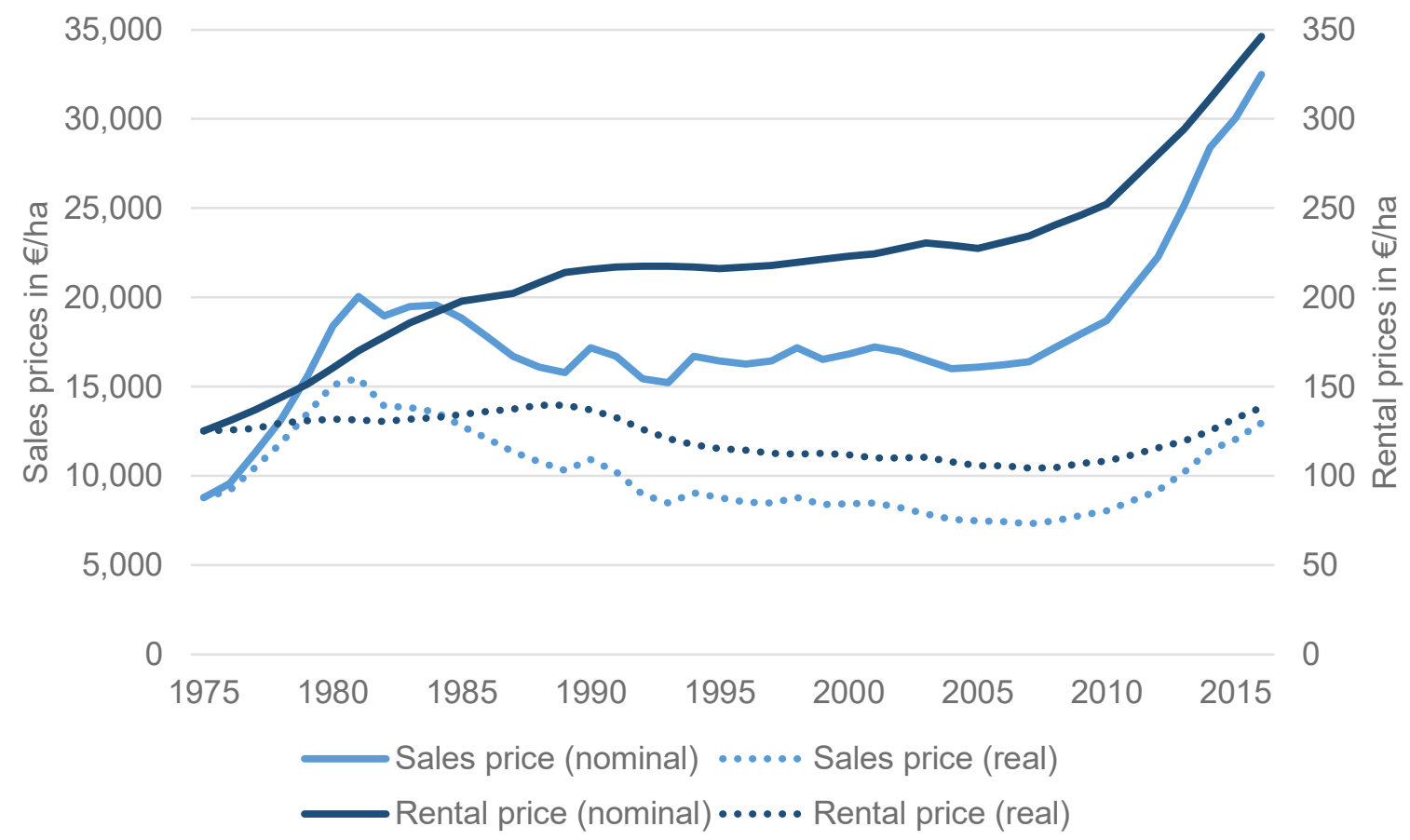

Time series of real sales prices and rental prices for the eight federal states of Western Germany are portrayed in Figure A1. Not surprisingly, sales prices vary considerably among states. They differ mostly with respect to the level. For example, prices in BadenWuerttemberg, Bavaria, and North Rhine-Westphalia are two times higher on average compared to Lower Saxony, Schleswig-Holstein, Hesse, Rhineland-Palatinate, and Saarland. 
Also, the price evolution follows different patterns. Prices in Bavaria and Lower Saxony have exhibited a strong increase in the last decade, while real land prices have stagnated or even declined in Saarland and Hesse. Similar findings apply to real rental prices (Fig. A1b).

Table 1 summarizes means and standard deviations of the core model variables, i.e., the rentprice ratio $\frac{R_{t}}{P_{t}}$, the growth rate of rental prices $\Delta r_{t}$, gross returns $\varphi_{t}$, and land premia $\pi_{t}$. Between 1975 and 2016, the average Western German rent-price ratio amounted to $1.26 \%$. In a static economic environment, this figure gives a clue about the profitability of investments into agricultural land. To put this value into perspective, a comparison with other markets is helpful. In the U.S., for example, the average rent-price ratio for farmland amounted to $5.4 \%$ between 1900 and 2012 and thus is considerably higher than in Western Germany (LENCE 2014). Also, rent-price ratios in real estate markets are typically higher, e.g., $3.75 \%$ in 2007 in the U.S. housing market (CAMPBELL et al., 2009) for similar time periods. This rather low rent-price ratio mirrors what has been labelled as the "farmland valuation puzzle" in the literature (e.g., LENCE and MILLER 1999). It describes the fact that rental prices appear low compared to sales prices. Again, we find pronounced regional differences between states. For example, the rent-price ratio in Schleswig-Holstein (2.2\%) is more than twice as high as in Baden-Wuerttemberg (0.84 \%).

Table 1. Descriptive statistics of model variables in \%, 1976-2016

\begin{tabular}{lrrrrrrrrr}
\hline & \multicolumn{2}{c}{$\frac{R_{t}}{P_{t}}$} & & \multicolumn{2}{c}{$\Delta r_{t}$} & & $\varphi_{t}$ & \multicolumn{2}{c}{$\pi_{t}$} \\
& Mean & SD & Mean & SD & Mean & SD & Mean & SD \\
\hline Western Germany & 1.264 & 0.170 & -0.027 & 2.374 & 2.419 & 6.673 & -0.511 & 7.487 \\
\hline Baden-Wuerttemberg & 0.836 & 0.152 & -0.251 & 1.898 & 0.390 & 5.113 & -2.539 & 5.892 \\
Bavaria & 0.845 & 0.148 & 0.269 & 2.499 & 2.875 & 9.153 & -0.054 & 9.848 \\
Hesse & 0.944 & 0.149 & -0.707 & 2.303 & -0.421 & 9.529 & -3.350 & 9.533 \\
Lower Saxony & 1.725 & 0.287 & 0.864 & 2.603 & 3.697 & 8.483 & 0.768 & 9.291 \\
North Rhine-Westphalia & 1.022 & 0.186 & 0.519 & 2.300 & 2.005 & 7.985 & -0.924 & 8.620 \\
Rhineland-Palatinate & 1.698 & 0.307 & -0.776 & 2.111 & 0.804 & 7.721 & -2.125 & 8.210 \\
Saarland & 0.827 & 0.130 & -1.026 & 2.504 & -0.300 & 8.631 & -3.230 & 8.763 \\
Schleswig-Holstein & 2.181 & 0.487 & 0.353 & 2.922 & 4.053 & 9.321 & 1.124 & 9.933 \\
\hline
\end{tabular}

Note: Here, the rent-price ratio $\frac{R_{t}}{P_{t}}$ is calculated for the period 1975-2016.

The time series of the rent-price ratio for Western Germany and selected federal states are depicted in Figure 2. In the late 1970s, the rent-price ratio in Western Germany exhibited a strong decrease due to surging sales prices. It reached a minimum of 0.8 , recovered thereafter and varied around a value of $1.3 \%$. In recent years, a decrease occurred again, yet less pronounced than in the eighties. Similar patterns can be observed in the selected federal states in Figure 2, even though the rent-price ratios differ in terms of the level. While Bavaria exhibits a lower rent-price ratio than the whole of Western Germany with around $0.8 \%$ on average, the rent-price ratios in Lower Saxony (Avg. $1.7 \%$ ) and Schleswig-Holstein (Avg. $2.2 \%$ ) are on average higher (see also Table 1). The standard deviation of the rent-price ratio in Table 1 depicts regional differences in the variability, which is highest in the federal states with higher 
rent-price ratios. The factors that cause this variation of the rent-price ratio will be inspected in greater detail in Section 4.2 .

\section{Figure 2. Rent-price ratio in Western Germany and selected federal states}

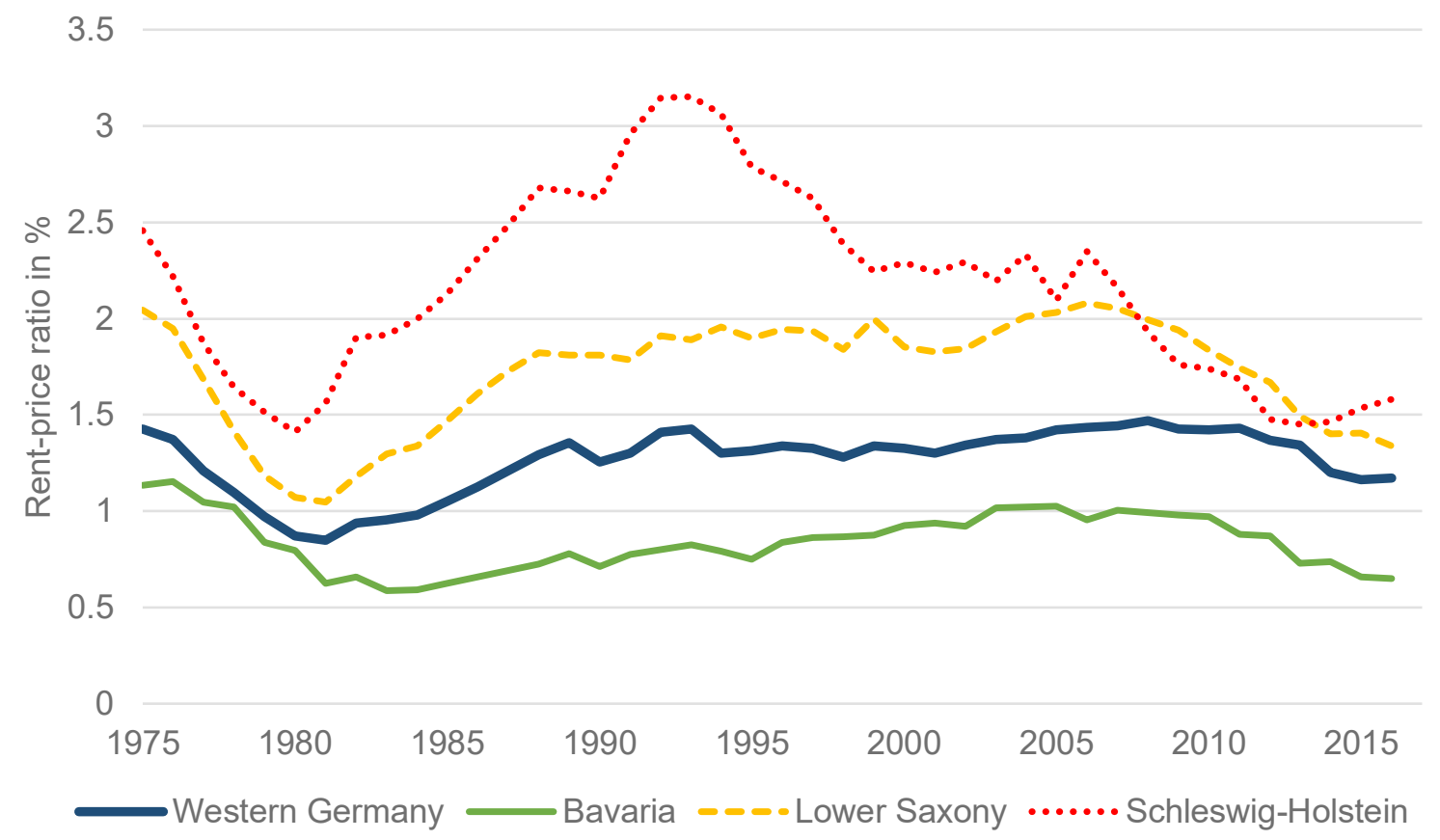

Table 1 also confirms that real rental rates for agricultural land stagnated on average in Western Germany during the observation period 1976-2016. Only Bavaria, Lower Saxony, North Rhine-Westphalia, and Schleswig-Holstein exhibit positive growth rates. Real returns on investing in agricultural land are positive, though modest $(2.4 \%$ on average for Western Germany). Investments in agricultural land in Lower Saxony and Schleswig-Holstein have the highest average return at around $4 \%$. Two states (Hesse and Saarland) even show negative returns. In light of these low returns, it is not surprising that the land premium, i.e., the excess return above the risk-free interest rate is negative for all states except Schleswig-Holstein.

Figure A2 in the Appendix gives an impression of the movement of interest rates, returns and land premia over time for Western Germany. As can be seen, returns and premia exhibit strong volatility, with high levels in the late 1970s and a subsequent strong decrease until 1981. Since then, both have increased slightly. Land premia became positive over the last decade as a result of increasing land prices and low real interest rates.

These findings may raise the question of how low or even negative returns can be rationalized. First, one has to recall that the figures reported in Table 2 are ex-post values, while investment decisions are based on ex-ante expectations. Second, the view of a financial investor, who buys land and leases it out thereafter, does not apply to the majority of transactions on land markets. Typically, farmers buy land for their own operations. In this case, their return is the marginal income generated by the production factor land and this value may exceed lease rates. Third, financial investors may benefit from risk reducing diversification effects. Fourth, tax benefits, which may constitute an additional incentive for farmers to pay high land prices, 
are not considered. Finally, in contrast to other financial assets, land may offer an intrinsic, non-monetary value to owners.

\section{Results}

\subsection{Specification and estimation results of the VAR}

We run a VAR over the study period 1976-2016. The lag order of the VAR is determined by means of the Bayesian Information Criterion (BIC). The BIC indicates that a first-order VAR is the adequate choice for the majority of the models, and we use this specification for all states:

$$
\left(\begin{array}{c}
\pi_{t} \\
i_{t} \\
\Delta r_{t}
\end{array}\right)=\left(\begin{array}{c}
\alpha_{\pi} \\
\beta_{\pi} \\
\gamma_{\pi}
\end{array}\right) \pi_{t-1}+\left(\begin{array}{c}
\alpha_{i} \\
\beta_{i} \\
\gamma_{i}
\end{array}\right) i_{t-1}+\left(\begin{array}{c}
\alpha_{\Delta r} \\
\beta_{\Delta r} \\
\gamma_{\Delta r}
\end{array}\right) \Delta r_{t-1}+\left(\begin{array}{c}
\varepsilon_{t}^{\pi} \\
\varepsilon_{t}^{i} \\
\varepsilon_{t}^{\Delta r}
\end{array}\right) .
$$

To estimate the VAR, we use seemingly unrelated regressions (SUR), which allow for dependencies in the error terms. We test the stability of the results by checking whether the modulus of the eigenvalues of the coefficient matrix is less than one. This stability condition is fulfilled for every VAR. The results for Western Germany are presented in Table 2. Our findings indicate that real return, real premium, and real rental growth are predictable to a moderate degree $\left(\bar{R}^{2}=0.54\right.$ and $\bar{R}^{2}=0.30$, respectively), whereas the real interest rate is highly predictable $\left(\bar{R}^{2}=0.89\right)$. For all three variables, only the coefficient of the own lagged variable is statistically significantly different from zero for Western Germany. The point estimates for the remaining federal states of Western Germany are summarized in Table A1 in the Appendix. Since significant non-diagonal coefficients occur for some states, we refrain from changing the model to a simple AR(1) model.

\section{Table 2. VAR estimation results for Western Germany}

\section{Estimated coefficient (standard error) for}

\begin{tabular}{|c|c|c|c|c|c|c|c|}
\hline \multirow{2}{*}{$\frac{\text { Dependent variable }}{\pi_{t}}$} & \multicolumn{2}{|c|}{$\pi_{t-1}$} & \multicolumn{2}{|c|}{$i_{t-1}$} & \multicolumn{2}{|c|}{$\Delta r_{t-1}$} & \multirow{2}{*}{$\frac{\bar{R}^{2}}{0.54}$} \\
\hline & $0.62^{* * *}$ & $(0.13)$ & -0.34 & $(0.24)$ & 0.46 & $(0.43)$ & \\
\hline$i_{t}$ & -0.002 & $(0.03)$ & $0.94^{\star * *}$ & $(0.05)$ & -0.04 & $(0.10)$ & 0.89 \\
\hline$\Delta r_{t}$ & 0.06 & $(0.05)$ & -0.03 & $(0.09)$ & $0.50^{* * *}$ & $(0.17)$ & 0.30 \\
\hline
\end{tabular}

Note: The asterisks ${ }^{* * *}$ denote statistical significance at the $1 \%$ significance level.

To increase the predictability of the variables, we also tried other model variants. Following CAMPBELL et al. (2009), we extended the VAR model by including further information that is available to market participants and might influence their expectations. More specifically, we chose the exit rate of agricultural farms as a proxy for land supply, because exiting of farms feeds land into local land markets. Moreover, we added the cereal yield growth rate to the model assuming that this variable represents productivity gains and thus the demand for agricultural land. However, the inclusion of these agricultural sector variables neither substantially increased the fit of the VAR model nor significantly changed the results and thus we do not report the results separately. 


\subsection{Components of the rent-price ratio}

Figure 3 presents the components of the rent-price ratio according to Eq. (6), i.e., expected present values for return $\left(\widehat{\Phi}_{t}\right)$ and rental growth $\left(\widehat{G}_{t}\right)$. Since expected values are estimated from past observations via a VAR, it is not surprising that the patterns of $\widehat{\Phi}_{t}$ and $\widehat{G}_{t}$ resemble those of the realizations of returns, $\varphi_{t}$, and rental growth, $\Delta r_{t}$, in Figure A2. Their levels differ because of the capitalization factor given in Eq. (9).

Figure 3. Expected present values of real return $\left(\widehat{\Phi}_{t}\right)$ and real rental growth $\left(\widehat{G}_{t}\right)$ of agricultural land in Western Germany

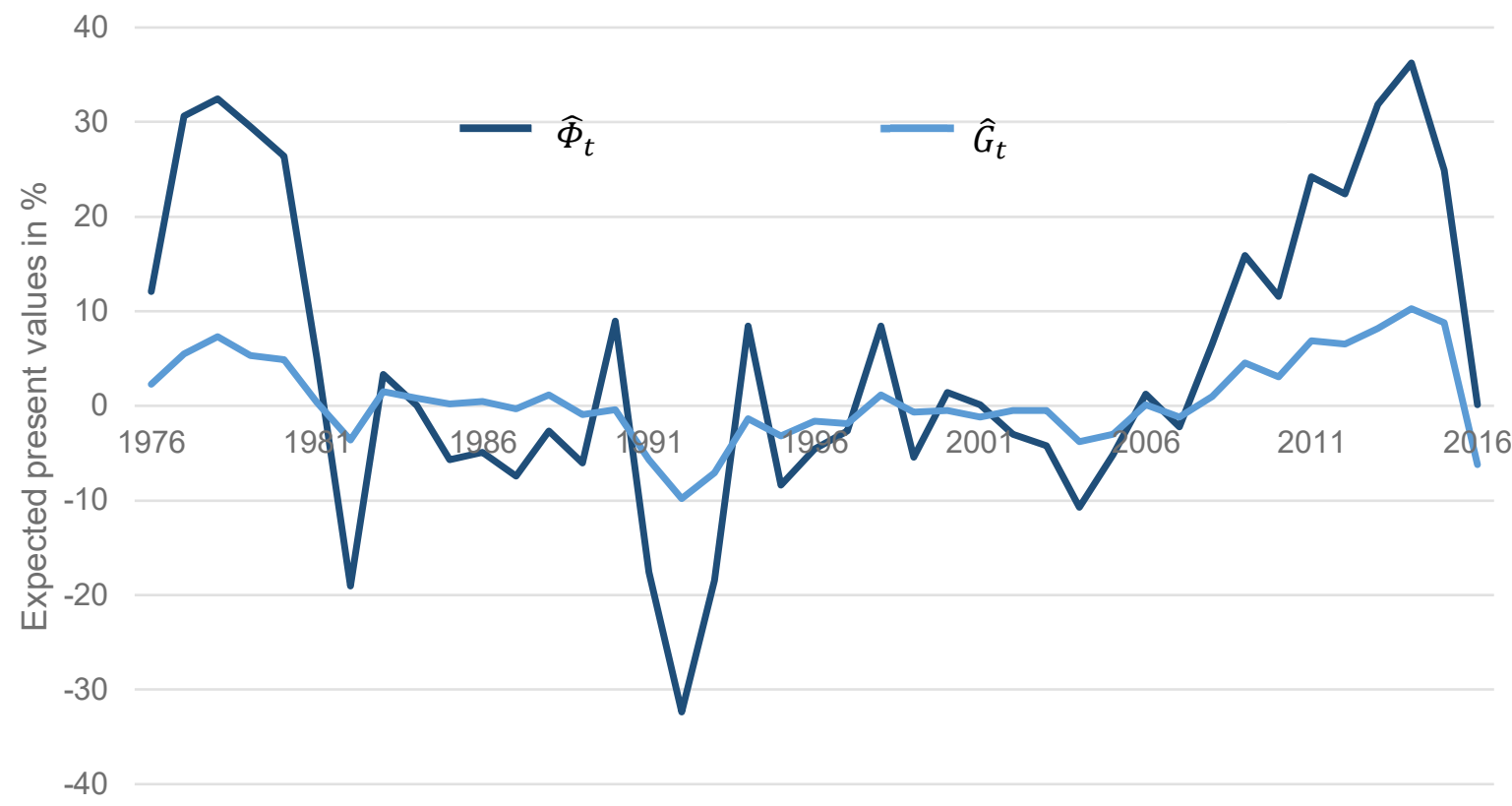

The dynamic Gordon growth model is an implicit model and it has not been designed to identify economic factors that underlie market fundamentals. However, it is tempting to construe the changing expectations of returns from an ex-post perspective. In doing so, three phases seem noteworthy:

First, expected future returns declined at the beginning of the eighties, which may reflect the discussions about budgetary problems of the Common Agricultural Policy (CAP) of the European Union, which eventually led to the introduction of milk quotas (CUNHA und SWINBANK 2011). This could have implied uncertainty and resulted in decreased expectations of rental growth rates, which in turn caused a plunge of returns in the formerly overheated land market.

Second, after a phase of consolidation, present values of expected returns show an overall minimum in 1992, a landmark in the CAP reform that resulted in the MacSharry reform, which changed the design of the CAP by partially shifting from price support to direct income support. It has been conjectured that the sensitivity of arable farmland values to governmental support increased in the aftermath of the reform (e.g., DUVIVIER et al. 2005). Right after 1992, expectations of future returns for agricultural land increased, reflecting resolved uncertainty as well as the monetary value of new income tools. Similar patterns are observed for the expected present value for rental growth. 
Third, after the decoupling of direct payments from production in 2003, expected future returns and rental growth rates increased towards an overall maximum in 2014. PATTON et al. (2008) and KILIAN et al. (2011) provide evidence that decoupled payments are capitalized to a stronger degree in farmland rental values than coupled payments which were granted before 2003. This effect could further be enhanced by several factors: On the one hand, the expansion of renewable energies in the beginning of the 2000s might have increased the value of land (HABERMANN and BREUSTEDT 2011; RITTER et al. 2015); on the other hand, surging food prices at that time led to a higher profitability of land (FAO 2018); furthermore, the financial crisis in $2007 / 08$ raised outside interest in investments into agricultural land.

After 2014, expected present values of return decreased sharply. This is in line with the finding of HÜTTEL et al. (2016) who report that a mean reversion of land rental prices was expected by market participants. This decrease correlates with the agricultural policy reform of 2014 , which replaced the Single Payment Scheme (SPS) with the Basic Payment Scheme (BPS). With the BPS, payments are split into basic payments, redistributive payments, payments for areas with natural or other specific constraints, and payments for young farmers. As a consequence of this reform, further constraints are involved in the granting of direct payments, so that certain farms, e.g., large farms, may have experienced a reduction of direct payments. This in turn might have scaled down expectations about future returns. Furthermore, in recent years, a reduction of these payments in favor of public welfare aspects was publicly discussed (e.g., BUCKWELL et al. 2017; WBAE 2018). In fact, it is widely acknowledged that direct income support in general drives farmland values (e.g., LATRUFFE and LE MOUËL 2009; BREUSTEDT and HABERMANN 2011). In addition, an amendment of the German Renewable Energy Act (EEG) was prepared in this period replacing fixed feed-in tariffs by auctions from 2017 on and hence lowering financial support. These recent discussions might have led market participants to downsize their expectations about future returns for land.

The aforementioned patterns are similar in most federal states of Western Germany, but some notable differences occur (see Figure A3a). For example, Bavaria experienced a stronger decrease in expectations of future returns in the early 1990s. A potential cause could be the particularly strong protests in Bavaria against the planned MacSharry reform in 1992 (WILSON and WILSON 2001). At the end of the study period, it can be seen that the expectation of future returns decreased earlier in Schleswig-Holstein compared to Bavaria and Lower Saxony. The latter two states might have expected stronger benefits from the 2013 CAP reform (LFL 2013).

Figure 4 decomposes the expected present values of the return on agricultural land into the present values of real risk-free interest rates and the present value of the land premium. This figure confirms the earlier findings that land premia were negative for three decades rendering investments in farmland unattractive for financial investors. This view changed in the aftermath of the financial crisis and the rush for land. The period of positive expected land premia, however, seems to be transient. In Figure A3b, the corresponding present values for the federal states are presented. 
Figure 4. Expected present values of real premium $\left(\widehat{\Pi}_{t}\right)$, real rental growth $\left(\widehat{G}_{t}\right)$ of agricultural land and real interest rate $\left(\hat{I}_{t}\right)$ in Western Germany according to Eq. (7)

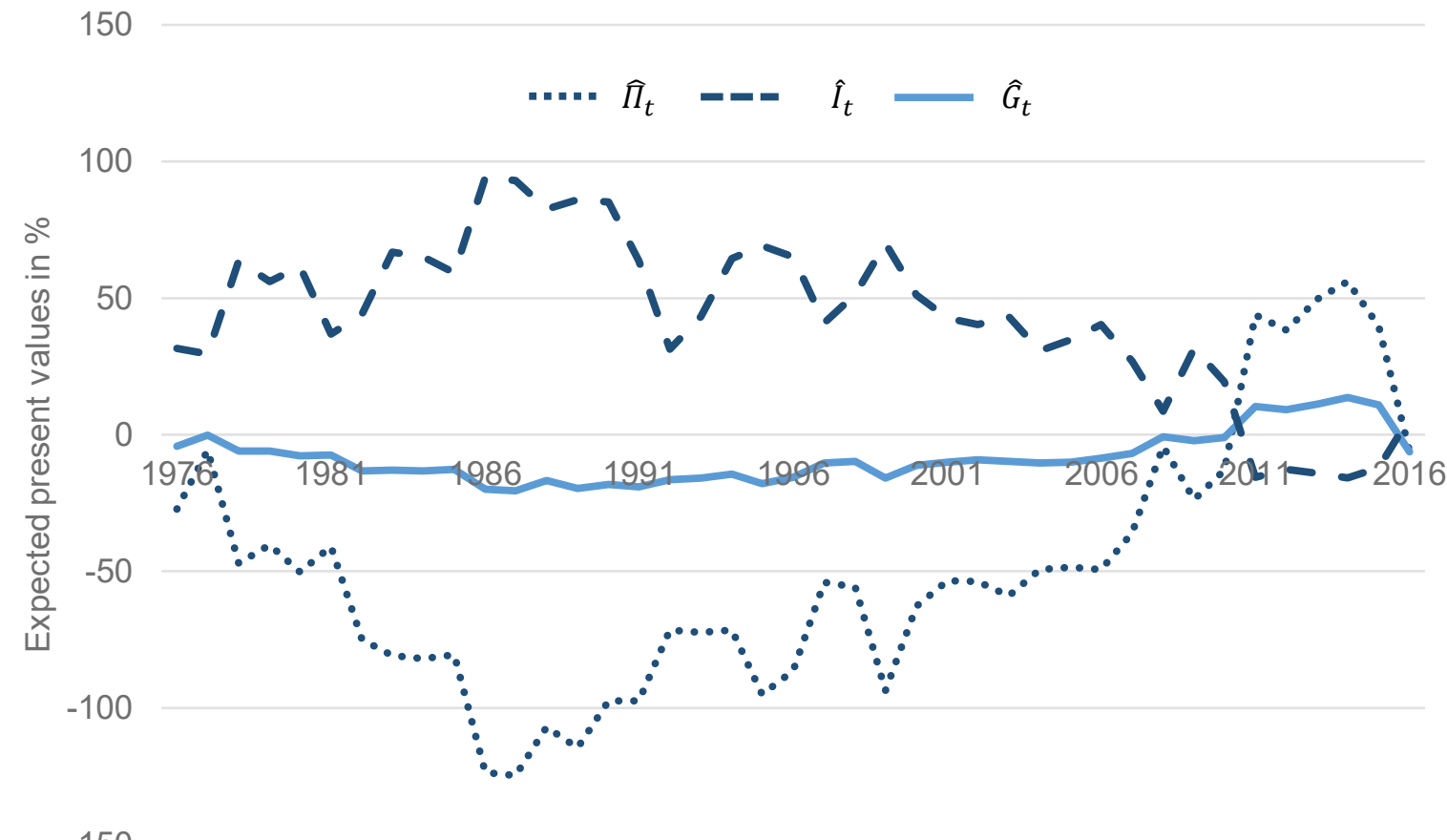

\subsection{Variance decomposition of the rent-price ratio}

Before decomposing the variance of the rent-price ratio, we compare the estimated rent-price ratio according to Eq. (10) in Figure 5 with the actual rent-price ratio in Figure 2 for Western Germany and selected federal states. Most remarkable is the level difference accruing between the actual and estimated rent-price ratio, which amounts to about 0.7 percentage points across the federal states. Following CAMPBELL and Shiller (1988), we refer this discrepancy to the constant $c$, the so-called free constant risk premium. This accrues to market participants expecting variability of the return. In the constant version of the Gordon growth model, this constant $c$ would be zero. By allowing for this free constant risk premium, we admit that this model captures the dynamics of the rent-price ratio rather than the mean level.

At the beginning and at the end of the observation period, the estimated rent-price ratios seem to be in line with the actual rent-price ratio, but Figure 5 also reveals periods where the estimated and actual rent-price ratio move in different directions. This inability of the estimated rent-price ratio to mimic movements of the actual rent-price ratio perfectly has been observed in other recent studies as well. CAMPBELL et al. (2009) explain this finding by arguing that the VAR is constructed to fit historical patterns of real return, real premium, real interest rate, and real rental growth, but not to fit the historical rent-price ratio. 


\section{Figure 5. Estimated rent-price ratio for Western Germany and selected federal states}

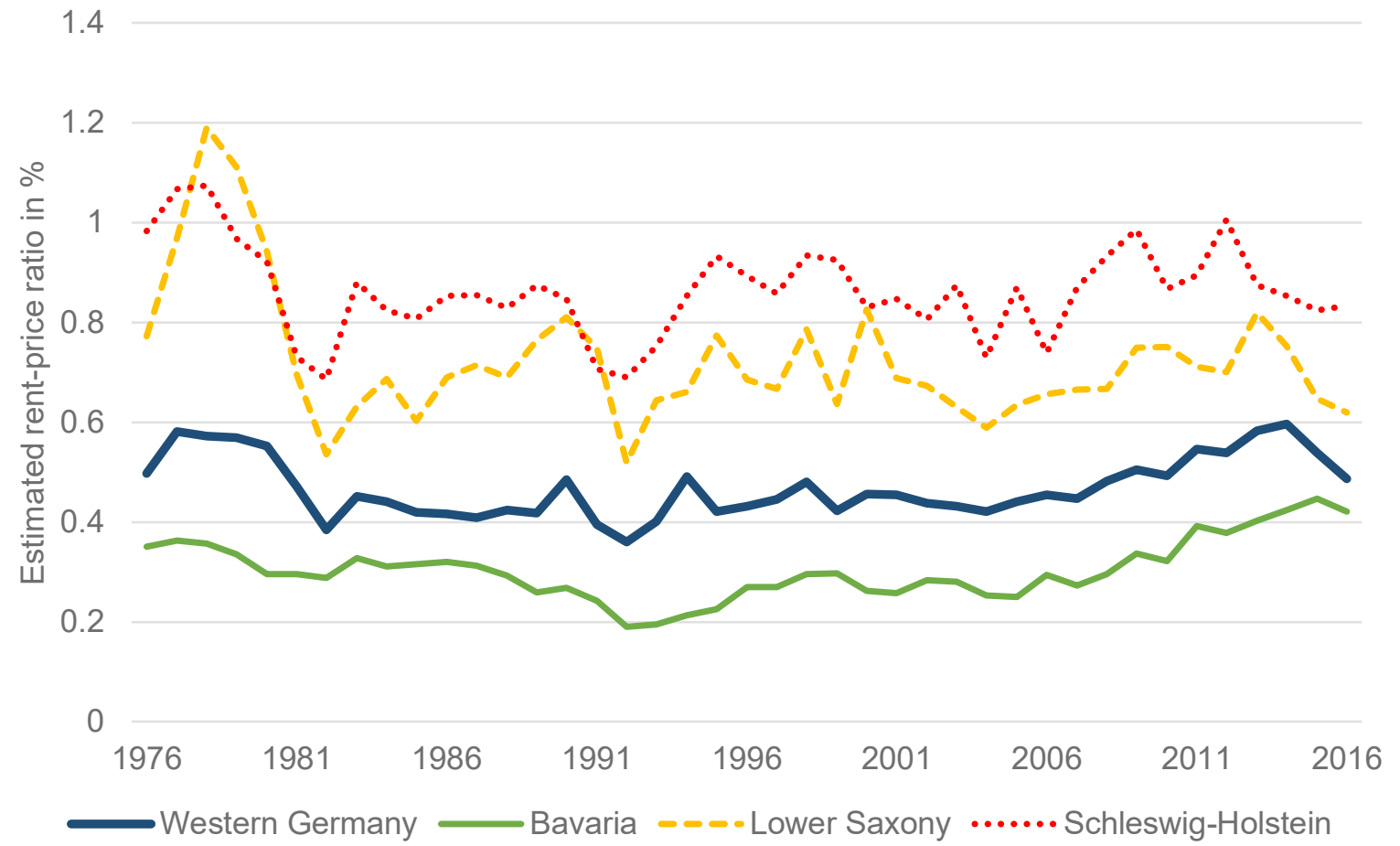

Table 3 summarizes the variance decomposition results of the log rent-price ratio according to Eq. (11). Comparing the variance of the estimated and the actual log rent-price ratio, we find that the former underestimates the latter in all cases except Bavaria. In Bavaria and Lower Saxony, the divergence between both variances is rather small. In Schleswig-Holstein, the divergence is higher, which implies that a larger share of the variance cannot be explained by the components of the dynamic Gordon growth model.

Regarding the importance of the individual components in Table 3, we find similar results for the federal states. The largest share of the variance results from $\widehat{\Pi}_{t}$, the estimated expected present value of the real premium to one hectare of agricultural land. The estimated expected present value of the real interest rate, $\hat{I}_{t}$, accounts for a lower share of the variance. Merging the premium and the interest rate shows a high relevance of the estimated expected present value of return, $\widehat{\Phi}_{t}$ (see bottom of Table 3 ). $\widehat{G}_{t}$, the estimated expected present value of real rental growth, and the residual $\epsilon_{t}$ account for the smallest share of the variance.

The observed variances are mostly in line with previous literature on the stock and housing markets. CAMPBELL et al. (2009), KIM and LIM (2014), and KISHOR and MORLEY (2015) identify $\widehat{\Pi}_{t}$ as the main source of rent-price ratio variability on the U.S. and Irish housing markets. Nevertheless, we observe some differences for the farmland market. BERNANKE and KUTTNER (2005) report for the stock market that the variance of expected present values of future premia, $\widehat{\Pi}_{t}$, is only three times as high as the variance of expected present values of future rental growth, $\hat{G}_{t}$, and CAMPBELL et al. (2009) report for the housing market a ratio of 2.5. In our analysis, however, we find clearly higher ratios, which is connected with our data preparation. First, the aforementioned linear interpolation of the rental price data reduces the variability. Second, the variability of the land premium data may be enhanced by the deflation of the interest rate via the CPI (see Section 3). 
Table 3. Variance decomposition of the log rent-price ratio for Western Germany and selected federal states, 1976-2016

\begin{tabular}{c|c|ccc}
\hline & Western Germany & Bavaria & Lower Saxony & Schleswig-Holstein \\
\hline $\operatorname{var}\left(r_{t}-p_{t}\right)$ & 0.022 & 0.031 & 0.034 & 0.054 \\
$\operatorname{var}\left(r_{t}-p_{t}\right)$ & 0.015 & 0.038 & 0.028 & 0.011 \\
\hline $\operatorname{var}\left(\widehat{\Pi}_{t}\right)$ & 0.215 & 0.808 & 0.447 & 0.329 \\
$\operatorname{var}\left(\hat{I}_{t}\right)$ & 0.088 & 0.178 & 0.181 & 0.067 \\
$\operatorname{var}\left(\widehat{G}_{t}\right)$ & 0.008 & 0.110 & 0.045 & 0.091 \\
$\operatorname{var}\left(\epsilon_{t}\right)$ & 0.048 & 0.078 & 0.077 & 0.083 \\
\hline $2 \operatorname{cov}\left(\widehat{\Pi}_{t}, \hat{I}_{t}\right)$ & -0.262 & -0.720 & -0.530 & -0.268 \\
$-2 \operatorname{cov}\left(\widehat{\Pi}_{t}, \widehat{G}_{t}\right)$ & -0.082 & -0.594 & -0.280 & -0.342 \\
$-2 \operatorname{cov}\left(\hat{I}_{t}, \widehat{G}_{t}\right)$ & 0.048 & 0.256 & 0.165 & 0.135 \\
$2 \operatorname{cov}\left(\hat{I}_{t}, \epsilon_{t}\right)$ & 0.034 & 0.085 & 0.027 & 0.067 \\
$2 \operatorname{cov}\left(\widehat{\Pi}_{t}, \epsilon_{t}\right)$ & -0.096 & -0.286 & -0.147 & -0.239 \\
$-2 \operatorname{cov}\left(\widehat{G}_{t}, \epsilon_{t}\right)$ & 0.021 & 0.116 & 0.049 & 0.131 \\
\hline $\operatorname{var}\left(\widehat{\Phi}_{t}\right)$ & 0.025 & 0.118 & 0.107 & 0.088 \\
$-2 \operatorname{cov}\left(\widehat{\Phi}_{t}, \widehat{G}_{t}\right)$ & -0.013 & -0.115 & -0.080 & -0.118 \\
$2 \operatorname{cov}\left(\widehat{\Phi}_{t}, \epsilon_{t}\right)$ & -0.051 & -0.141 & -0.176 & -0.156 \\
\hline
\end{tabular}

Note: The last three rows (variances and covariances including $\widehat{\Phi}_{t}$ ) are based on a different VAR model, where $Z_{t}=\left(\varphi_{t}, \Delta \mathrm{r}_{t}\right)$.

In Table 3, we also find evidence about the relationship between the components of the dynamic Gordon growth model. Altogether, the covariances between the components dampen the total variation of the rent-price ratio. The positive covariance between $\widehat{\Pi}_{t}$ and $\hat{G}_{t}$ contributes negatively to the total variation. This is also the case for $\widehat{\Phi}_{t}$ and $\hat{G}_{t} . \widehat{\Pi}_{t}$ and $\hat{I}_{t}$, however, are negatively correlated, which also implies a negative contribution. The results reported for Western Germany are similar in the selected federal states and vary only in their relative size. It is not surprising that $\widehat{\Pi}_{t}$ and $\widehat{G}_{t}$, respectively $\widehat{\Phi}_{t}$ and $\widehat{G}_{t}$, are positively correlated. If future rents are expected to grow, future prices tend to rise, and both together will increase the expected present values of future returns, respectively premia (cf. Eq. (1)). Of particular interest, however, are the negative correlations between $\widehat{\Pi}_{t}$ and $\hat{I}_{t}$ and $\hat{G}_{t}$ and $\hat{I}_{t}$. These could further support the hypothesis that owning land offers potential for portfolio diversification of financial investors.

\section{Conclusions}

Agricultural land is a complex asset, which is held for various reasons. The approach that we pursue in this paper considers land as a financial asset. This particular view is motivated by the ongoing discussion about land as being an attractive investment opportunity for agricultural and non-agricultural investors. In contrast to the majority of analyses that aim to explain either land price or rental price levels, we focus on the relationship between sales and rental prices. In a static economic environment, the rent-price ratio provides a first indicator of the profitability of an investment in land. To allow a more sophisticated analysis, we apply a decomposition of the rent-price ratio and its variance into the (expected) growth rates, real interest rates, and a land premium that represents an excess return on investment. 
Applying this model to sales and rental prices in Western Germany over four decades reveals a couple of interesting findings: First, it turns out that the recent land price surge, which has triggered intense discussions about tightening land market regulations (c.f. ODENING and HÜTTEL 2018), is not unprecedented. Actually, real land prices were higher in the eighties. Second, the rent-price ratio amounts to a mere $1.3 \%$ on average and is low compared to real estate or stock markets. That is, agricultural land is rather "expensive" in relation to earnings from renting it out. This can be explained by the fact that land is a production factor, which can generate income that exceeds land rents, by the existence of intrinsic values for land owners or by option values related to future non-agricultural use (e.g., TURVEY 2003). Interestingly, the rent-price ratio varies considerably among states: On average, it is more than two times higher in Schleswig-Holstein than in Bavaria or Baden-Wuerttemberg. Though our model does not provide an explanation for this gap, it suggests that differences regarding price formation on land markets are in place, which might reflect different farm structures in the various federal states. For example, farms in Schleswig-Holstein manage more land and have a lower share of own land on average than farms in Bavaria. Moreover, different cultural attitudes, e.g., emotional links to farm land, may explain regional variation of the rent-price ratio. Third, considering the components of the rent-price ratio, we observe rather low returns on investments in land. Land premia, i.e., returns beyond a risk-free interest rate, are even negative on average in Western Germany, rendering investments in land unprofitable for financial investors at least from an ex post perspective. Finally, a variance decomposition of the rent-price ratio shows that changing expectations of present values of returns on land investments are the major driver for land price volatility while expected present values of rental growth are relatively stable.

The policy implications of our results are quite obvious since they challenge the view of agricultural land as a profitable investment opportunity for financial investors. Rent seeking financial investors, however, are the key ingredient for the "land grabbing" narrative that drives the current policy debate about land market regulation in the EU (e.g., VAN DER PLOEG et al. 2015, KAY et al. 2015). In our study region, positive land premia emerged only for a few years in the last decade and seem to have vanished again in recent years. We do not question that financial investors are engaged on agricultural land markets in Germany, however, our results cast doubt that a "rush" on land from outside the sector will take place in the near future. This assessment is also confirmed by CROONENBROECK et al. (2018), who report that only $1 \%$ of all BVVG auctions in Eastern Germany have been won by foreign investors. Overall, these findings query the need for stricter land market regulations that protect farmers against financial investors. 


\section{References}

Ambrose, B.W., P. EICHHOLTZ and T. Lindenthal (2013): House Prices and Fundamentals: 355 Years of Evidence. Journal of Money, Credit and Banking 45 (2-3): 477-491.

BERNANKE B.S. and K.N. KUTTNER (2005): What explains the Stock's Market Reaction to Federal Reserve Policy? The Journal of Finance 60 (3):1221-1257

BReustedt, G. and H. HABERMANN. (2011): The Incidence of EU Per-Hectare Payments on Farmland Rental Rates: A Spatial Econometric Analysis of German Farm-Level Data. Journal of Agricultural Economics, 62 (1): 225-243

BuCKWELL, A., A. MATTHEWS, D. BALDOCK and E. MATHIJS (2017). CAP - Thinking Out of the Box: Further modernisation of the CAP - Why, what and how? RISE Foundation, Brussels.

BUND-LÄNDER-ARBEITSGRUPPE "BODENMARKTPOLITIK" (2015). Landwirtschaftliche Bodenmarktpolitik: Allgemeine Situation und Handlungsoptionen. Abschlussbericht. https://www.bmel.de/SharedDocs/Downloads/Landwirtschaft/LaendlicheRaeume/Boden markt-Abschlussbericht-Bund-Laender-Arbeitsgruppe.html (last accessed 04.10.2018)

CAMPBELL, J. Y. and R. J. SHILLER (1988):The Dividend-Price Ratio and Expectations of Future Dividends and Discount Factors. The Review of Financial Studies 1(3): 195-228.

CAMPBELL, J. (1991): A variance decomposition for stock returns. Economic Journal 101 (405): 157-179.

CAmpBeLL, J. Y. and J. AmmeR. (1993): What moves the Stock and Bond markets? A Variance Decomposition for Long-Term Asset Returns. The Journal of Finance 48 (1): 3-37

CAMPBELL, S., M. A. DAVIS, J. GALLIN and R.F. MARTIN (2009): What moves housing markets: A variance decomposition of the rent-price ratio. Journal of Urban Economics 66 (2): 90-102.

CLARK, J.S., M. FULTON and J.T. SCOTT (1993): The Inconsistency of Land Values, Land Rents, and Capitalization Formulas. American Journal of Agricultural Economics 75(1): 147-155.

Croonenbroeck, C., M. Odening, S. HÜtTel (2018): Farmland Values and Bidder Behavior in First-Price Land Auctions. Humboldt-Universität zu Berlin. FORLand-Working Paper 02(2018). http://dx.doi.org/10.18452/18966

CUNHA, A. and A. SWINBANK (2011): An Inside View of the CAP Reform Process: Explaining the MacSharry, Agenda 2000, and Fischler Reforms. Oxford Sholarship Online.

DEININGER, K. and D. BYERLEE (2011): Rising Global Interest in Farmland. The World Bank, Washington D.C.

DUVIVIER R., F. GASPART and B. HENRY DE FRAHAN (2005): A panel data analysis of the determinants of farmland price: an application to the effects of the 1992 CAP reform in Belgium, Paper presented at the XIth EAAE Congress, Copenhagen, Denmark, August 23-27

EUROPEAN COMMISSION (2018): Agricultural land prices by region. https://ec.europa.eu/eurostat/web/products-datasets/product?code=apri Iprc (last accessed (05.10.2018)

FALK, B. (1991): Formally Testing the Present Value Model of Farmland Prices. American Journal of Agricultural Economics 73(1):1-10.

FALK, B. and B.S. LEE (1998): Fads versus Fundamentals in Farmland Prices. American Journal of Agricultural Economics 80(4): 696-707.

FAO (2018): Food Outlook: Biannual report on global food markets. http://www.fao.org/3/ca0239en/CA0239EN.pdf (last accessed 04.10.2018)

FEICHTINGER, P. and K. SALHOFER (2013): What Do We Know about the Influence of Agricultural Support on Agricultural Land Prices? German Journal of Agricultural Economics 62(2): 71-83.

ForstneR, B., A. TietZ, K. KLARE, W. KLeinhanss and P. Weingarten (2011): Aktivitäten von nichtlandwirtschaftlichen und überregional ausgerichteten Investoren auf dem landwirtschaftlichen Bodenmarkt in Deutschland. Landbauforschung Völkenrode, Sonderheft 352, Braunschweig. 
GLOY, B.A., M.D. BOEHLJE, C.L. DobBINS, C. HuRT and T.G. BAKER (2011): Are Economic Fundamentals Driving Farmland Values? Choices Quarter 2. http://choicesmagazine.org/choices-magazine/theme-articles/farmland-values/areeconomic-fundamentals-driving-farmland-values (last accessed on 04.10.2018)

HABERMANN, H. and G. BREUSTEDT (2011): Impact of Biogas Production on Farmland Rental Rates in Germany. German Journal of Agricultural Economics 60(2): 85-100.

HENNIG, S., G. BREUSTEDT and U. LATACZ-LohmANN (2014): The Impact of Payment Entitlements on Arable Land Prices and Rental Rates in Schleswig-Holstein. German Journal of Agricultural Economics 63 (4): 219-239.

HENNIG, S. and U. LATACZ-LOHMANN (2017): The incidence of biogas feed-in tariffs on farmland rental rates - evidence from northern Germany. European Review of Agricultural Economics 44 (2): 231-254.

HÜTTEL, S., M. RITTER, V. ESAULOV and M. OdENING (2016): Is there a term structure in land lease rates? European Review of Agricultural Economics 43 (1): 165-187.

HütTEL, S., L. WILDERMANN and C. CROONENBROECK (2016): How Do Institutional Market Players Matter in Farmland Pricing? Land Use Policy 59: 154-167.

KAY, S., J. PEUCH and J. FRANCO (2015): Extent of Farmland Grabbing in the EU. Study on behalf of the European Parliament's Committee on Agriculture and Development. PE 540.369. Brussels.

KILIAN, S., J. ANTON, N. RÖDER AND K. SALHOFER (2008): Impacts of 2003 CAP reform on land prices: from theory to empirical results: Paper presented at the 109th annual meeting ofthe European Association of Agricultural Economists, Viterbo Italy, November 20-21.

KIM, J. and G. LIM (2014): Understanding the Irish price-rent ratio: an unobserved component approach. Applied Economics Letters 21(12): 836-841.

KISHOR, N.K. and J. MORLEY (2015): What factors drive the price-rent ratio for the housing market? A modified present value analysis. Journal of Economic Dynamics \& Control (58): 235-248.

KUETHE, T.H., J. IFFT and M. MOREHART (2011): The Influence of Urban Areas on Farmland Values. Choices. Quarter 2. http://choicesmagazine.org/choices-magazine/themearticles/farmland-values/the-influence-of-urban-areas-on-farmland-values (last accessed 04.10.2018)

LATRUFFE, L. and C. MOUEL (2009): Capitalization of Government Support in Agricultural Land Prices: What Do We Know? Journal of Economic Surveys 23(4): 659-691.

LEHN, F. and E. BAHRS (2018): Analysis of factors influencing standard farmland values with regard to stronger interventions in the German farmland market. Land Use Policy 73: 138-146.

LENCE, S.H. (2014): Farmland Prices: Is This Time Different? Applied Economic Perspectives and Policy 36 (4): 577-603.

LENCE, S.H. and D.J. MILLER (1999): Transaction Costs and the Present Value Model of Farmland: lowa, 1900-1994. American Journal of Agricultural Economics 81(2): 257272.

LFL (2013): EU-Förderperiode 2014-2020 - Direktzahlungen. Bayerische Landesanstalt für Landwirtschaft. https://www.Ifl.bayern.de/publikationen/informationen/056322/ (last accessed 05.10.2018)

ODENING, M. and S. HÜTTEL (2018): Müssen landwirtschaftliche Bodenmärkte vor Investoren geschützt werden? Eine ökonomische Perspektive. FORLand Policy Brief 01/2018. https://ageconsearch.umn.edu/record/276288.

OLSEN, B.C. and J.R. STOKES (2015): Is Farm Real Estate The Next Bubble? Journal of Real Estate Finance and Economics 50: 355-376.

PATTON, M., P. Kostov, S. MCERLEAN and J. Moss (2008): Assessing the influence of direct payments on the rental value of agricultural land. Food Policy 33: 397-405

PLAZZI, A., W. TOROUS and R. VALKANOV (2006). Expected returns and the expected growth in rents of commercial real estate. Working Paper, University of California, Los Angeles

POWER, G. and C. TURVEY (2010): U.S. rural land value bubbles. Applied Economics Letters 17: 649-656. 
RitTeR, M., S. HÜTTEL, M. WALTER and M. OdENING (2015): Der Einfluss von Windkraftanlagen auf landwirtschaftliche Bodenpreise. Berichte über Landwirtschaft 93(3). http://dx.doi.org/10.12767/buel.v93i3.83

STATISTISCHES BUNDESAMT (2018): Land- und Forstwirtschaft, Fischerei: Kaufwerte für landwirtschaftliche Grundstücke.

https://www.destatis.de/DE/Publikationen/Thematisch/Preise/Baupreise/KaufwerteLand wirtschaftlicheGrundstuecke.html (last accessed 04.10.2018)

SHILLER, R. and A. BELTRATTI (1992): Stock prices and bond yields: can their comovements be explained in terms of present value models? Journal of Monetary Economics 30 (1): 25-46.

TIETZ, A. and B. FORSTNER (2014): Spekulative Blasen auf dem Markt für landwirtschaftlichen Boden. Berichte über Landwirtschaft 92(3). http://dx.doi.org/10.12767/buel.v92i3.63.g147

TURVEY, C.G. (2003): Hysteresis and the Value of Farmland: A Real-Options Approach to Farmland Valuation. In: Moss, C.B., Schmitz, A. (eds.): Government Policy and Farmland Markets, lowa State Press: 179-207.

VAN DER PLOEG, J.D., J.C. FRANCO and S.M. BORRAS (2015): Land concentration and land grabbing in the EU: a preliminary analysis. Canadian Journal of Development Studies 36(2): 147-162.

VuOLTEENAHO, T. (2002): What Drives Firm-Level Stock Returns? The Journal of Finance, 57 (1): 233-264.

WBAE (2018): "Für eine gemeinwohlorientierte Gemeinsame Agrarpolitik der EU nach 2020: Grundsatzfragen und Empfehlungen". Gutachten des Wissenschaftlichen Beirats für Agrarpolitik, Ernährung und gesundheitlichen Verbraucherschutz beim Bundesministerium für Ernährung und Landwirtschaft

WILSON, G. A. and O. J. WILSON (2001): German Agriculture in Transition: Society, Policies and Environment in a Changing Europe. Palgrave New York.

ZHANG, W. and C. NICKERSON (2015): Housing market bust and farmland values: Identifying the changing influence of proximity to urban centers. Land Economics 91(4): 605-626. 


\section{Appendix}

\section{Figure A1. Real prices for the federal states of Western Germany}

a) Sales prices

80,000

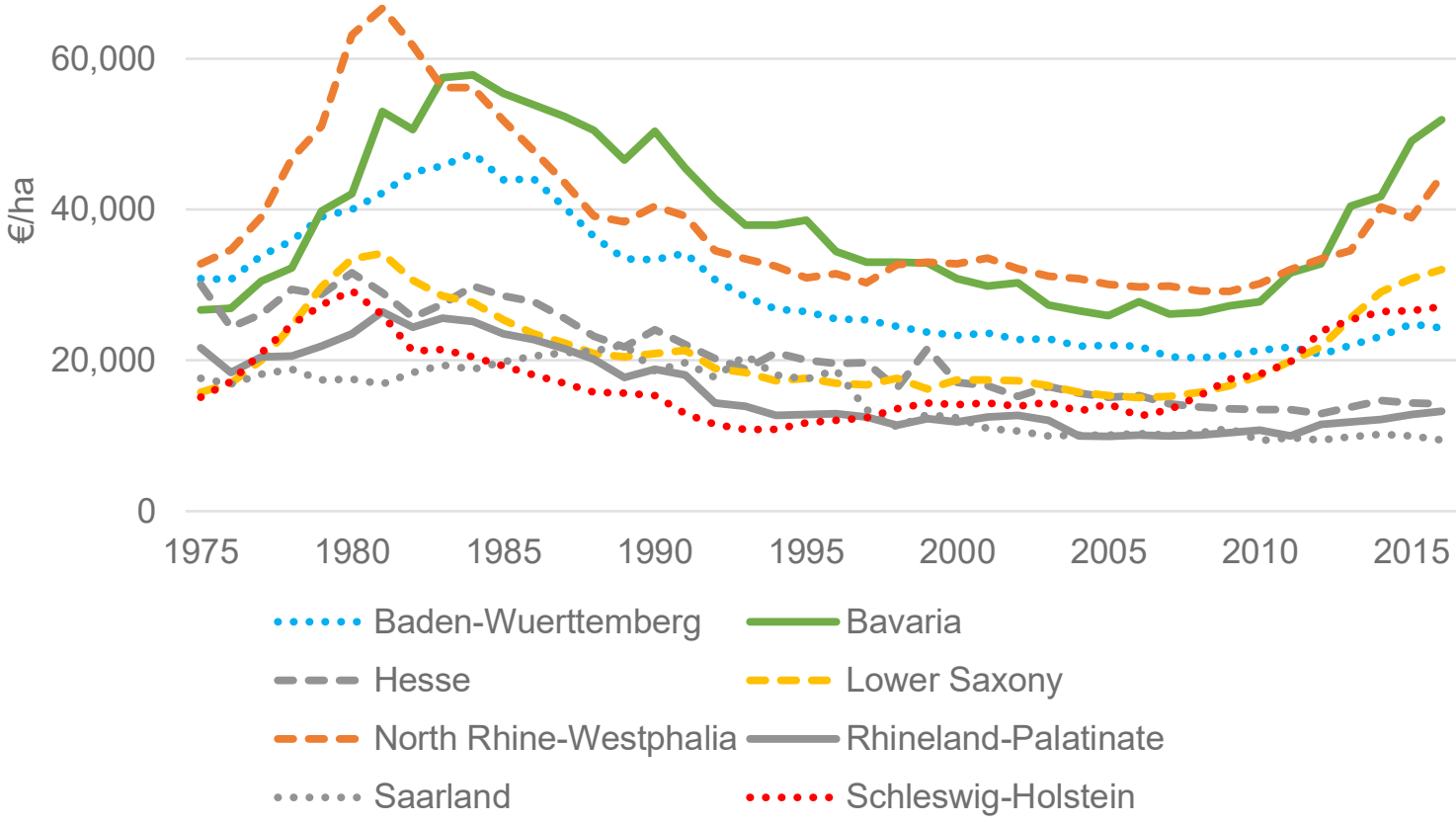

b) Rental prices

500

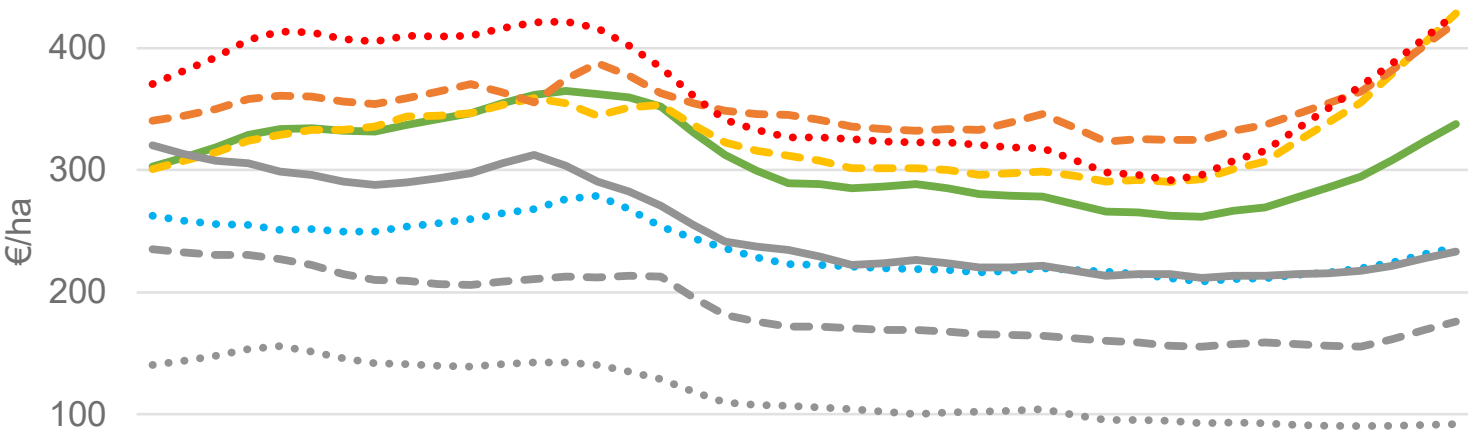

0

\begin{tabular}{lllllllll}
\hline 1975 & 1980 & 1985 & 1990 & 1995 & 2000 & 2005 & 2010 & 2015
\end{tabular}

..... Baden-Wuerttemberg Bavaria

- - Hesse - - - Lower Saxony

- - North Rhine-Westphalia Rhineland-Palatinate

Saarland $\quad$...... Schleswig-Holstein 
Figure A2. Real risk-free interest rate for Germany $\left(i_{t}\right)$, real rental growth rate for agricultural land in Western Germany $(\Delta r)$, return for agricultural land in Western Germany $\left(\varphi_{t}\right)$, and premium for agricultural land in Western Germany $\left(\pi_{t}\right)$

20

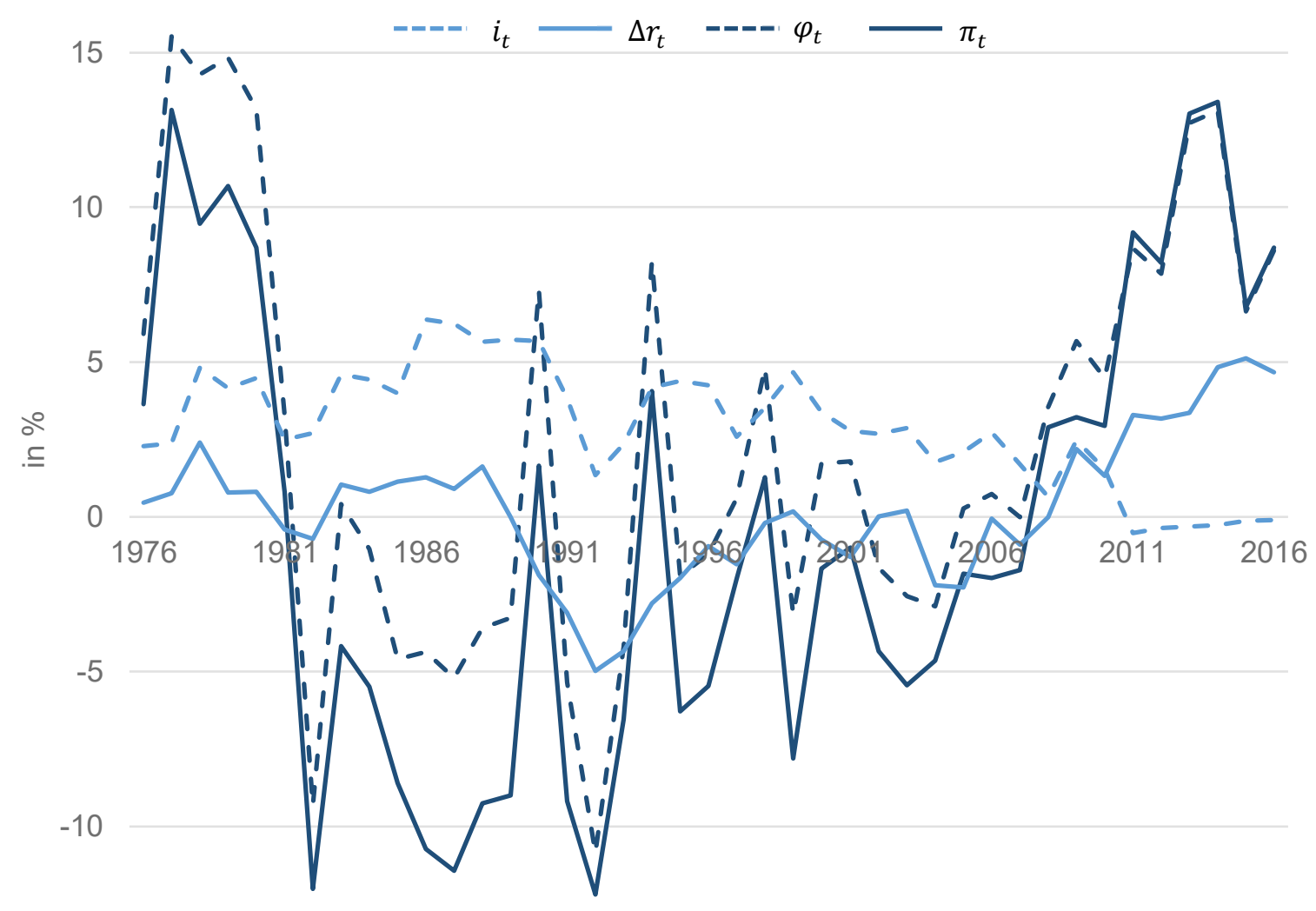


Figure A3. Expected present values in \% in Bavaria, Lower Saxony and SchleswigHolstein, 1976-2016

a) ... of real return $\left(\widehat{\Phi}_{t}\right)$ and real rental growth $\left(\widehat{G}_{t}\right)$ of agricultural land

100

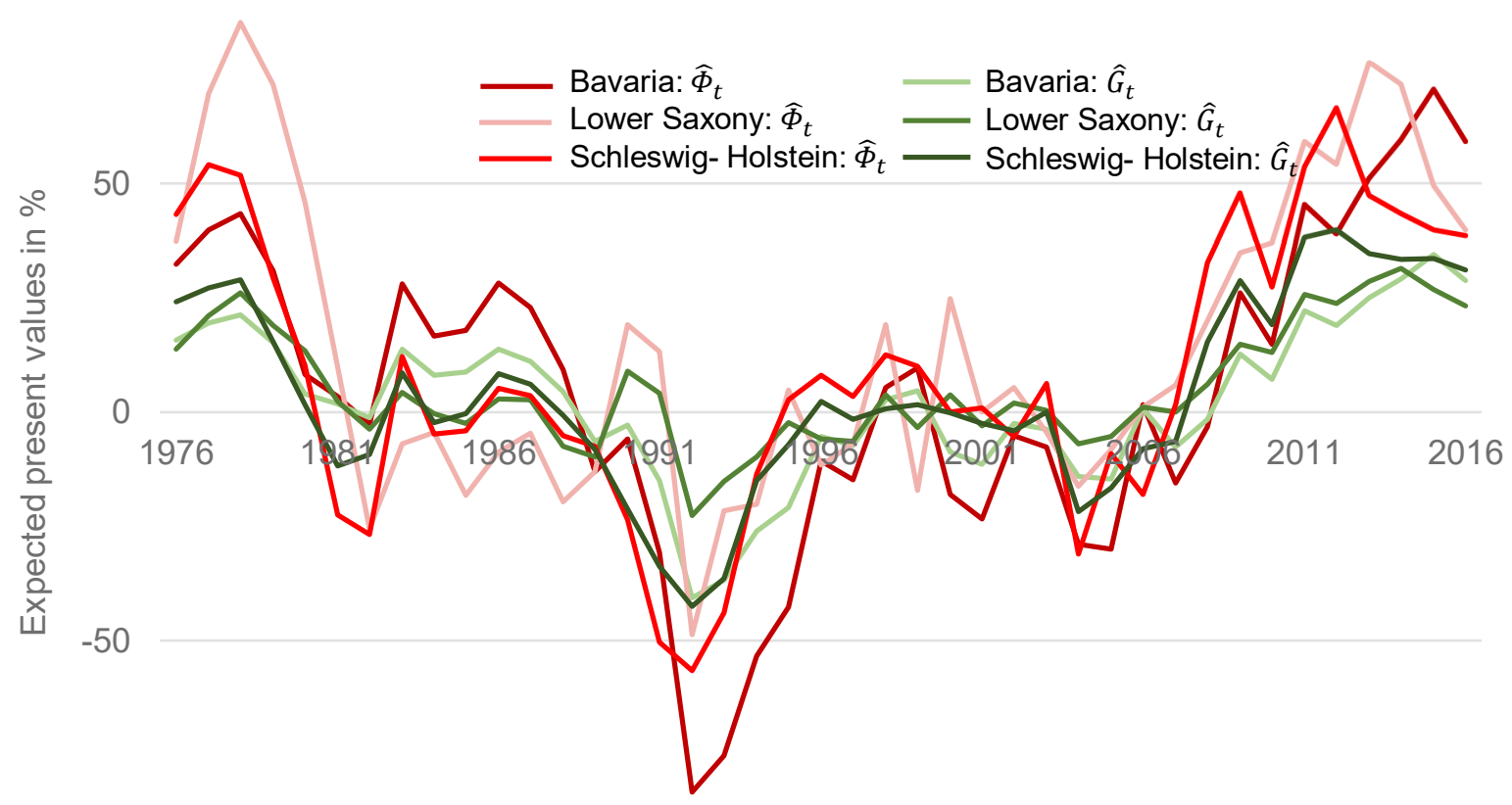

b) ... of real premium $\left(\widehat{\Pi}_{t}\right)$, real rental growth $\left(\widehat{G}_{t}\right)$ of agricultural land and real interest rate $\left(\widehat{I}_{t}\right)$

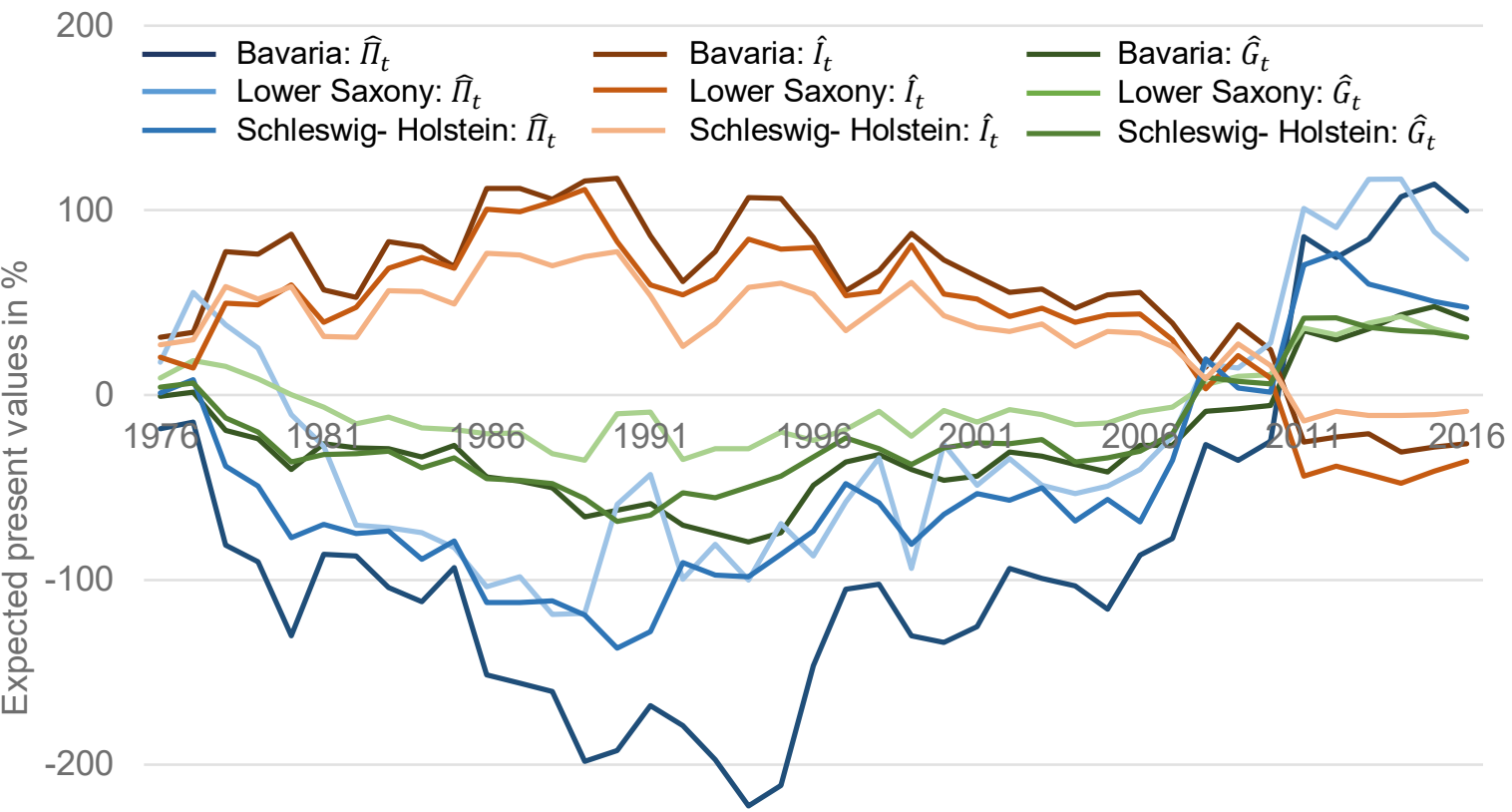


Table A1. VAR estimation results for the federal states of Western Germany

\begin{tabular}{|c|c|c|c|c|c|c|c|}
\hline \multirow{3}{*}{$\begin{array}{l}\text { Dependent Variables in } \\
\text { Baden-Wuerttemberg } \\
\pi_{t}\end{array}$} & \multicolumn{6}{|c|}{ Estimated coefficient (standard error) for } & \multirow{3}{*}{$\frac{\bar{R}^{2}}{0.46}$} \\
\hline & \multicolumn{2}{|c|}{$\pi_{t-1}$} & \multicolumn{2}{|c|}{$i_{t-1}$} & \multicolumn{2}{|c|}{$\Delta r_{t-1}$} & \\
\hline & $0.45^{* * *}$ & $(0.14)$ & -0.57 & $(0.26)$ & 0.14 & $(0.40)$ & \\
\hline$i_{t}$ & -0.01 & $(0.03)$ & $0.93^{* * *}$ & $(0.06)$ & 0.02 & $(0.10)$ & 0.89 \\
\hline$\Delta r_{t}$ & $0.07^{* *}$ & $(0.04)$ & 0.01 & $(0.06)$ & $0.74^{* * *}$ & $(0.09)$ & 0.63 \\
\hline Bavaria & \multicolumn{2}{|c|}{$\pi_{t-1}$} & \multicolumn{2}{|c|}{$i_{t-1}$} & \multicolumn{2}{|c|}{$\Delta r_{t-1}$} & $\bar{R}^{2}$ \\
\hline$\pi_{t}$ & 0.03 & $(0.16)$ & -0.62 & $(0.40)$ & $1.78^{* * *}$ & $(0.64)$ & 0.54 \\
\hline$i_{t}$ & 0.02 & $(0.02)$ & $0.95^{\star * *}$ & $(0.05)$ & -0.07 & $(0.08)$ & 0.89 \\
\hline$\Delta r_{t}$ & 0.04 & $(0.02)$ & -0.05 & $(0.05)$ & $0.80^{* * *}$ & $(0.09)$ & 0.73 \\
\hline Hesse & \multicolumn{2}{|c|}{$\pi_{t-1}$} & \multicolumn{2}{|c|}{$i_{t-1}$} & \multicolumn{2}{|c|}{$\Delta r_{t-1}$} & $\bar{R}^{2}$ \\
\hline$\pi_{t}$ & $-0.34^{* *}$ & $(0.14)$ & $-1.48^{* * *}$ & $(0.39)$ & 0.08 & $(0.58)$ & 0.25 \\
\hline$i_{t}$ & -0.03 & $(0.02)$ & $0.89^{* * *}$ & $(0.05)$ & $-0.15^{\star *}$ & $(0.07)$ & 0.91 \\
\hline$\Delta r_{t}$ & 0.01 & $(0.03)$ & -0.10 & $(0.08)$ & $0.67^{* * *}$ & $(0.12)$ & 0.49 \\
\hline Lower Saxony & \multicolumn{2}{|c|}{$\pi_{t-1}$} & \multicolumn{2}{|c|}{$i_{t-1}$} & \multicolumn{2}{|c|}{$\Delta r_{t-1}$} & $\bar{R}^{2}$ \\
\hline$\pi_{t}$ & $0.70^{* \star \star}$ & $(0.13)$ & -0.16 & $(0.45)$ & 0.38 & $(0.45)$ & 0.59 \\
\hline$i_{t}$ & 0.01 & $(0.02)$ & $0.94^{* * *}$ & $(0.05)$ & -0.08 & $(0.08)$ & 0.89 \\
\hline$\Delta r_{t}$ & 0.05 & $(0.03)$ & -0.01 & $(0.08)$ & $0.73^{* * *}$ & $(0.12)$ & 0.64 \\
\hline North Rhine-Westphalia & \multicolumn{2}{|c|}{$\pi_{t-1}$} & \multicolumn{2}{|c|}{$i_{t-1}$} & \multicolumn{2}{|c|}{$\Delta r_{t-1}$} & $\bar{R}^{2}$ \\
\hline$\pi_{t}$ & $0.45^{* \star *}$ & $(0.13)$ & $-0.50^{*}$ & $(0.31)$ & $1.23^{* \star *}$ & $(0.46)$ & 0.42 \\
\hline$i_{t}$ & -0.03 & $(0.02)$ & $0.91^{* * *}$ & $(0.05)$ & 0.06 & $(0.08)$ & 0.89 \\
\hline$\Delta r_{t}$ & 0.01 & $(0.04)$ & -0.03 & $(0.09)$ & $0.59^{* * *}$ & $(0.14)$ & 0.29 \\
\hline Rhineland-Palatinate & \multicolumn{2}{|c|}{$\pi_{t-1}$} & \multicolumn{2}{|c|}{$i_{t-1}$} & \multicolumn{2}{|c|}{$\Delta r_{t-1}$} & $\bar{R}^{2}$ \\
\hline$\pi_{t}$ & 0.02 & $(0.16)$ & $-0.88^{* *}$ & $(0.37)$ & $0.36^{* *}$ & $(0.58)$ & 0.15 \\
\hline$i_{t}$ & -0.02 & $(0.02)$ & $0.90^{* * *}$ & $(0.06)$ & -0.07 & $(0.09)$ & 0.89 \\
\hline$\Delta r_{t}$ & 0.03 & $(0.03)$ & $-0.13^{*}$ & $(0.07)$ & $0.60^{* * *}$ & $(0.11)$ & 0.56 \\
\hline Saarland & \multicolumn{2}{|c|}{$\pi_{t-1}$} & \multicolumn{2}{|c|}{$i_{t-1}$} & \multicolumn{2}{|c|}{$\Delta r_{t-1}$} & $\bar{R}^{2}$ \\
\hline$\pi_{t}$ & $-0.24^{*}$ & $(0.15)$ & $-1.51^{* * *}$ & $(0.26)$ & $-0.36^{* * *}$ & $(0.40)$ & 0.22 \\
\hline$i_{t}$ & -0.01 & $(0.02)$ & $0.94^{* * *}$ & $(0.06)$ & -0.05 & $(0.06)$ & 0.89 \\
\hline$\Delta r_{t}$ & $0.07^{\star *}$ & $(0.03)$ & -0.10 & $(0.08)$ & $0.65^{\star \star \star}$ & $(0.10)$ & 0.59 \\
\hline Schleswig-Holstein & \multicolumn{2}{|c|}{$\pi_{t-1}$} & \multicolumn{2}{|c|}{$i_{t-1}$} & \multicolumn{2}{|c|}{$\Delta r_{t-1}$} & $\bar{R}^{2}$ \\
\hline$\pi_{t}$ & $0.49^{* * \star}$ & $(0.14)$ & -0.36 & $(0.34)$ & -0.57 & $(0.51)$ & 0.38 \\
\hline$i_{t}$ & 0.01 & $(0.02)$ & $0.94^{* * *}$ & $(0.05)$ & -0.04 & $(0.07)$ & 0.89 \\
\hline$\Delta r_{t}$ & 0.04 & $(0.02)$ & -0.07 & $(0.06)$ & $0.81^{* * *}$ & $(0.09)$ & 0.79 \\
\hline
\end{tabular}

Note: The asterisks *, ${ }^{* *}$, and ${ }^{* *}$ denote statistical significance at the $10 \%, 5 \%$, or $1 \%$ significance level, respectively. 